\title{
Pengaruh Mikoriza dan Mikroba Pelarut Fosfat Terhadap Serapan P dan Pertumbuhan dan Produksi Kacang Hijau (Vigna radiata L.) Pada Bekas Lahan Sawah
}

\author{
Nursiani Lubis \\ Program Studi Agroteknologi, Universitas Amir Hamzah \\ Nursianilubis@gmail.com
}

\begin{abstract}
Abstrak
Kacang hijau merupakan salah satu tanaman pangan sumber protein nabati. Kacang hijau (Vigna radiata L.) termasuk komoditas tanaman kacang-kacangan yang umumnya ditanam di lahan kering. Penelitian ini bertujuan untuk mengetahui respon pertumbuhan dan produksi kacang hijau dengan memanfaatkan Mikroba Pelarut Fosfat dan Mikoriza pada bekas lahan sawah. Penelitian ini merupakan rancangan eksperimental yang menggunakan metode Rancangan Acak Kelompok (RAK) faktorial dengan menggunakan 2 faktor dengan 3 ulangan. Faktor I : Aplikasi Mikoriza (M) M0 : Tanpa mikoriza (0 g/tanaman) M1 : $5 \mathrm{~g} /$ tanaman M2 : 10 g/tanaman M3 : $15 \mathrm{~g} /$ tanaman. Faktor II : Aplikasi Mikroba Pelarut Fosfat (P) P0 : Tanpa mikroba pelarut fosfat P1 : Penicillium sp Mursala $20 \mathrm{~mL} / \operatorname{tanaman} \mathrm{P} 2$ : Penicillium $\mathrm{sp}$ Lab 20 mL/tanaman. Peubah Amatan yang dilakukan dalam penelitian ini adalah Rasio Tajuk Akar, Serapan Hara P, Persentase Polong Bernas dan Bobot 100 biji / tanaman. Hasil dari penelitian ini menujukkan bahwa Aplikasi mikoriza 15 g/tanaman merupakan dosis terbaik untuk meningkatkan serapan $\mathrm{P}(2,74 \mathrm{mg} / \mathrm{tanaman})$ dan produksi kacang hijau. Interaksi antara mikoriza $15 \mathrm{~g} /$ tanaman dan Penicillium $\mathrm{sp}$ Mursala meningkatkan serapan $\mathrm{P}(3,20 \mathrm{mg} / \mathrm{tanaman})$ dan produksi kacang hijau. Interaksi mikoriza $15 \mathrm{~g} /$ tanaman dan Penicillium sp Mursala menghasilkan bobot 100 biji/tanaman sebesar 6,67 g/tanaman
\end{abstract}

Keyword : Kacang Hijau, Mikoriza, Mikroba Pelarut Fosfat, Lahan Sawah

Jurnal Insitusi Politeknik Ganesha Medan 


\section{PENDAHULUAN}

Kacang hijau merupakan salah satu tanaman pangan sumber protein nabati. Kandungan protein kacang hijau sebesar 22\% menempati urutan ketiga setelah kedelai dan kacang tanah (Purwono dan Hartono, 2005). Kacang hijau (Vigna radiata L.) termasuk komoditas tanaman kacang-kacangan yang umumnya ditanam di lahan kering. Kacang hijau memiliki potensi yang besar sebagai produk olahan maupun bahan makanan campuran dan telah memiliki keunggulan kompetitif tertentu dibandingkan jenis kacang yang lain. Biji kacang hijau mengandung nilai gizi yang tinggi berupa vitamin B, mineral, dan serat (Dostalova, 2009).

Berdasarkan data Badan Pusat Statistik (2015), produksi kacang hijau di Indonesia mengalami penurunan dari 341.342 ton/tahun menjadi 271.463 ton/tahun (tahun 2011 dibanding 2015). Berbagai factor menyebabkan penurunan produksi kacang hijau, antara lain kesuburan tanah rendah, alih fungsi lahan, faktor iklim tidak mendukung, dan praktik budidaya tidak tepat.

Salah satu jenis tanah yang dapat digunakan untuk bertanam kacang hijau adalah lahan sawah. Hardjowigeno dan Rayes (2005) menyatakan bahwa lahan sawah biasanya digunakan untuk bertanam padi, baik secara terus menerus sepanjang tahun maupun bergiliran dengan tanaman palawija. Upaya untuk memenuhi kebutuhan kacang hijau dalam negeri dapat dilakukan dengan cara meningkatkan produksi melalui intensifikasi atau teknik budidaya pada lahan sawah. Menurut Biro Pusat Statistik (2014) menyatakan bahwa luas lahan sawah di Indonesia sekitar 8.132.345 ha. Namun, Luas lahan sawah terdegradasi mencapai 4.477.459 ha, dimana seluas 1.777 .679 ha mengalami degradasi berat dan sisanya terdegradasi ringan-sedang.

Menurunnya produktivitas lahan sawah memerlukan upaya pemulihan secara tepat dan cepat. Tanah sakit diartikan sebagai menurunnya kemampuan tanah dalam mendukung pertumbuhan tanaman secara berkelanjutan. Penurunan (degradasi) produktivitas lahan sawah dicirikan antara lain oleh menurunnya kandungan bahan organik tanah dan rendahnya ketersediaan unsur hara makro P.

Hasil penelitian Badan Litbang Pertanian (2006) menunjukkan bahwa sekitar 17\% persen dari 7,9 juta ha lahan sawah di Indonesia memiliki kadar total $\mathrm{P}$ tanah yang rendah. Salah satu cara untuk mengatasi ketersediaan unsuk P dengan bioteknologi tanah, yaitu memanfaatkan mikroba tanah yang memiliki kemampuan dalam melarutkan dan menyerap $\mathrm{P}$ dalam tanah seperti Mikroba Pelarut Fosfat dan Mikoriza, sehingga kebutuhan tanaman yaitu unsur $\mathrm{P}$ dapat terpenuhi

Penggunaan mikoriza merupakan salah satu alternatif dalam mengatasi permasalahan tersebut. Cendawan Mikoriza dalam upaya membantu tanah untuk melepaskan fosfor yang terserap Al di dalam tanah secara cepat. Keistimewaan dari

Jurnal Insitusi Politeknik Ganesha Medan 
jamur ini adalah kemampuannya dalam membantu tanaman untuk menyerap dan menguraikan unsur hara terutama unsur hara fosfor (P) (Madjid, 2009).

Disamping bermanfaat terhadap perkembangan struktur tanah, mikoriza juga sangat berperan dalam meningkatkan serapan unsur hara, terutama unsur fosfor $(\mathrm{P})$. Mekanisme penyerapan unsur $\mathrm{P}$ dengan adanya kolonisasi mikoriza terjadi melalui Hifa dalam tanah mengarbsopsi Pdan mengangkutnya ke akar-akar yang dikolonisasi, dimana P ditransfer ke inang bermikoriza (Fuady, 2013). Menurut hasil percobaan Husna (2016). Aplikasi FMA menghasilkan pertumbuhan dan produksi kacang hijau lebih tinggi dibandingkan tanpa FMA melalui peningkatan tinggi tanaman $(12,46 \%)$, jumlah cabang $(8,88 \%)$, bobot akar segar $(14,34 \%)$, bobot tajuk kering $(19,36 \%)$, bobot akar kering $(28,24 \%)$, jumlah bintil $(28,71 \%)$, jumlah bintil efektif $(27,74 \%)$, serapan P $(46,72 \%)$, bobot 50 butir biji $(11,56 \%)$, bobot biji per tanaman $(24,02 \%)$, dan infeksi akar $(85,62 \%)$.

Peningkatan efesiensi pemupukan $\mathrm{P}$ antara lain dapat dilakukan dengan inokulasi mikroba pelarut fosfat. Unsur P dalam bahan organik dilepaskan melalui proses mineralisasi melibatkan organisme tanah. Aktivitas mikroba ini sangat dipengaruhi oleh kelembaban tanah dan suhu. $\mathrm{P}$ anorganik bermuatan negatif di sebagian besar tanah. $\mathrm{P}$ bereaksi dengan besi $(\mathrm{Fe})$ bermuatan positif, aluminium $(\mathrm{Al})$, dan kalsium (Ca) untuk membentuk zat relatif tidak larut. Kadar kalsium (Ca) yang tinggi dalam tanah akan menghambat kelarutan fosfat alam, sedangkan tanah yang mempunyai kadar Ca rendah akan mendorong pelarutan fosfat alam secara terus menerus (Balai Penelitian Tanah, 2012). Penelitian ini bertujuan untuk mengetahui respon pertumbuhan dan produksi kacang hijau (Vigna radiata L.) dengan memanfaatkan Mikroba Pelarut Fosfat dan Mikoriza pada bekas lahan sawah.

\section{TINJAUAN PUSTAKA}

\section{Kacang Hijau (Vigna radiata $\mathrm{L}$ )}

Kacang hijau dikenal dengan beberapa nama, seperti mungo, mung bean, green bean (inggris) dan choroko (bahasa Swahili, India). Di Indonesia, kacang hijau juga memilki beberapa nama daerah, seperti Artak (Madura), Wilis (Bali), Buwe (Flores), dan Tibowong Candi (Makassar) (Astawan, 2009). Sedangkan menurut kedudukan dalam taksonomi tumbuhan, kacang hijau diklasifikasikan sebagai berikut : Division : Spermatophyta; Classis : Magnoliophyta; Order : Fabales; Family : Fabaceae Genus : Vigna ; Species : Vigna radiata L var VIMA-I (Puluhulawa, 2014).

Morfologi tanaman kacang hijau varietas VIMA-I menurut Dinas Pertanian Gorontalo (2012) yaitu tanaman kacang hijau tumbuh tegak dengan tinggi mencapai $53 \mathrm{~cm}$, cabangnya menyamping pada batang utama, berbentuk bulat dan berbulu. Warna batang dan cabangnya hijau dan bila sudah tua batang akan berubah menjadi warna coklat gelap. Daunnya majemuk dan terdiri dari tiga helai daun berbentuk oval dengan bagian ujung lancip dan berwarna hijau muda hingga hijau

Jurnal Insitusi Politeknik Ganesha Medan 
tua.Letak daun berseling. Tangkai daun lebih panjang daripada daunnya sendiri. Bunganya berwarna kuning, muncul di ujung percabangan pada umur 29 - 33 hari. Polong berbentuk silindris dengan panjang antara setelah tua berwarna coklat dan setiap polong berisi 10 - 15 biji. Bijinya berwarna hijau kusam.

\section{Mikroba Pelarut Fosfat}

Ketersediaan fosfor dalam tanah jarang yang melebihi $0,01 \%$ dari total $\mathrm{P}$. Sebagian besar bentuk fosfor terikat oleh koloid tanah sehingga tidak tersedia bagi tanaman (Husen, 2009). Pada tanah masam, fosfat akan bersenyawa dengan aluminium membentuk Al-P, sedangkan pada kondisi basa fosfat akan bersenyawa dengan kalsium membentuk Ca-P yang sukar larut. Alternatif untuk meningkatkan efesiensi fosfor yang tidak tersedia adalah dengan memanfaatkan mikroba pelarut fosfat sehingga fosfat yang tidak tersedia menjadi tersedia, sehingga dapat diserap oleh tanaman.

Mikroba ini juga diketahui mampumemproduksi asam amino, vitamin, serta sustansi pemacu pertumbuhan seperti IAA dan Giberelin yang dapat membantu pertumbuhan tanaman (Ponmurugan dan Gopi, 2006). Selain itu mikroba ini juga mampu menahan penetrasi patogen akar karena sifat mikroba yang cepat mengkolonisasi akar dan menghasilkan senyawa antibiotik (Elfiati, 2005)

\section{Mikoriza}

Mikoriza merupakan hubungan mutualistik antara akar dan cendawan. Tumbuhan inang menyediakan fungi dengan suplai gula yang tetap. Sementara itu, cendawan meningkatkan area permukaan bagi pengambilan air dan juga menyuplai tumbuhan dengan fofat dan mineral-mineral lain diabsorbsi dari tanah. Mikorizajuga menyekresikan faktor faktor pertumbuhan yang merangsang akar untuk tumbuh dan bercabang, seperti antibiotik yang membantu melindungi tumbuhan dari patogenpatogen dalam tanah (Campbell, 2010).

Simbiosis mutualistik utama mikoriza terdiri dari dua tipe : ektomikoriza dan mikoriza arbuskula (endomikoriza). Dalam ektomikoriza, miselium (masa hifa yang bercabang) membentuk selubung yang rapat, atau mantel, dipermukaan akar. Hifa cendawan membentang dari mantel ke dalam tanah, sehingga meningkatkan area permukaan absorpsi air dan mineral. Hifa juga tumbuh ke dalam korteks akar. Hifa ini tidak menembus sel-sel akar namun membentuk jejaring diapoplas, atau rongga ekstraseluler, yang memfasilitasi pertukaran nutrisi antara fungi dan tumbuhan (Campbell, 2010).

\section{Lahan Sawah}

Tanah sawah adalah tanah yang digunakan untuk bertanam padi sawah, baik terus menerus sepanjang tahun maupun bergiliran dengan tanaman palawija. Istilah tanah sawah bukan merupakan istilah taksonomi tanah, tetapi merupakan istilah umum seperti halnya tanah hutan, tanah perkebunan, tanah pertanian dan sebagainya. Sawah yang airnya berasal dari irigasi disebut sawah irigasi sedang yang menerima 
langsung dari air hujan disebut sawah tadah hujan. Di daerah pasang surut ditemukan sawah surut sedangkan yang dikembangkan daerah rawa-rawa lebak disebut sawah lebak (Hardjowigeno dan Rayes, 2005).

Menurut Badan Pusat Statistik (2015) lahan sawah di Indonesia yaitu seluas 8.087.393 ha, luas lahan sawah yang terletak di Provinsi Sumatera Utara yaitu seluas 423.465 ha. Sanchez (1993) membagi profil tanah sawah atas 4 (empat) bagian sebagai berikut: 1 . Tanah sawah lapisan air 2. Tanah sawah lapisan oksidasi 3. Tanah sawah lapisan olah yang mengalami reduksi 4. Tanah sawah lapisan subsoil yang bersifat oksidatif dan kadang-kadang reduktif.

\section{METODE PENELITIAN}

Penelitian ini dilaksanakan di Lahan Sawah Pasar II Tanjung Sari, Medan, Sumatera Utara dan Laboratorium Biologi Tanah, Fakultas Pertanian, Universitas Sumatera Utara, Medan dengan ketinggian tempat $\pm 25 \mathrm{~m}$ di atas permukaan laut pada bulan Oktober 2018 sampai dengan Maret 2019.

Bahan yang digunakan dalam penelitian ini adalah benih kacang hijau var VIMAI, Tanah komposit yang berasal dari pulau Mursala (vegatasi tanaman kapur barus), inokulan Mikoriza asal pulau Mursala (koleksi), Inokulan Penicillium sp. Lab (213 x $107 \mathrm{CFU} / \mathrm{mL})$, Inokulan Penicillium sp asal pulau Mursala (272 x $107 \mathrm{CFU} / \mathrm{mL})$, pupuk kimia (Urea (0,5 g/tanaman), SP36 (0,25 g/tanaman dan $\mathrm{KCl}(1 \mathrm{~g} / \operatorname{tanaman}))$. Alat-alat yang digunakan terdiri alat untuk analisis tanah dan tanaman di Laboratorium.

Penelitian ini merupakan rancangan eksperimental yang menggunakan metode Rancangan Acak Kelompok (RAK) faktorial dengan menggunakan 2 faktor dengan 3 ulangan. Faktor I adalah aplikasi mikoriza dan faktor II adalah inokulasi mikroba pelarut fosfat. Perlakuan mikoriza dibagi menjadi 4 taraf sedangkan perlakuan mikroba pelarut fosfat diberikan dengan 2 taraf dan dilakukan pencampuran antara jamur dan bakteri pelarut fosfat yang dapat diuraikan sebagai berikut : Faktor I : Aplikasi Mikoriza (M) M0 : Tanpa mikoriza (0 g/tanaman) M1 : $5 \mathrm{~g} / \operatorname{tanaman}$ M2 : $10 \mathrm{~g} /$ tanaman M3 : $15 \mathrm{~g} /$ tanaman. Faktor II : Aplikasi Mikroba Pelarut Fosfat (P) P0 : Tanpa mikroba pelarut fosfat P1 : Penicillium sp Mursala $20 \mathrm{~mL} / \operatorname{tanaman} \mathrm{P} 2$ : Penicillium sp Lab $20 \mathrm{~mL} / \mathrm{tanaman}$

Data hasil penelitian dianalisis dengan sidik ragam, data yang berpengaruh nyata dilanjutkan dengan uji beda rataan berdasarkan Duncan Multiple Range Test (DMRT) pada taraf 5\%. Peubah Amatan yang dilakukan dalam penelitian ini adalah Rasio Tajuk Akar, Serapan P, Persentase Polong Bernas dan Bobot 100 biji/tanaman.

Jurnal Insitusi Politeknik Ganesha Medan

Juripol, Volume 4 Nomor 2 Septembar 2021 


\section{HASIL DAN PEMBAHASAN}

\section{Rasio Tajuk Akar}

Hasil sidik ragam rasio tajuk akar menunjukkan bahwa aplikasi mikoriza dan mikroba pelarut fosfat serta interaksi kedua faktor tidak berpengaruh nyata terhadap rasio tajuk akar. Aplikasi mikoriza dan mikroba pelarut fosfat serta interaksinya terhadap rasio tajuk akar disajikan pada Tabel 1.

Tabel 1. Rerata rasio tajuk akar dengan pemberian mikoriza dan mikroba pelarut fosfat pada lahan sawah.

\begin{tabular}{|c|c|c|c|c|}
\hline \multirow[b]{2}{*}{ Mikoriza } & \multicolumn{3}{|c|}{ Penicillium sp $20 \mathrm{~mL} / \operatorname{tanaman}$} & \multirow[b]{2}{*}{ Rataan } \\
\hline & $\begin{array}{c}\text { Tanpa } \\
\text { Penicillium }\end{array}$ & $\begin{array}{l}\text { Penicillium sp } \\
\text { Mursala }\end{array}$ & $\begin{array}{l}\text { Penicillium } \\
\text { sp Lab }\end{array}$ & \\
\hline --g/tanaman-- & \multicolumn{4}{|c|}{------------------------------'mg/tanaman------------------------------------ } \\
\hline 0 & 4,13 & 4,27 & 4,60 & 4,33 \\
\hline 5 & 4,22 & 4,27 & 4,54 & 4,34 \\
\hline 10 & 4,20 & 4,42 & 4,54 & 4,39 \\
\hline 15 & 4,27 & 4,67 & 4,64 & 4,53 \\
\hline Rataan & 4,21 & 4,42 & 4,58 & \\
\hline
\end{tabular}

Dari Tabel 1 menunjukkan bahwa perlakuan mikoriza dan mikroba dapat meningkatkan rasio tajuk akar namun tidak berbeda nyata antara semua perlakuan. Rasio tajuk akar tertinggi diperoleh dari kombinasi pemberian mikoriza $15 \mathrm{~g}$ dan Penicillium sp Mursala yaitu 4,67, sedangkan rasio tajuk akar terendah diperoleh dari tanpa aplikasi mikoriza dan tanpa aplikasi mikroba pelarut fosfat yaitu 4,13 g/tanaman.

Pemberian mikoriza membantu pertumbuhan akar tanaman dengan adanya hifahifa mikoriza pada akar tanaman. Pemberian $15 \mathrm{~g} /$ tanaman mikoriza asal Mursala dapat meningkatkan pertumbuhan akar sebesar 2,24 g dibandingkan tanpa pemberian mikoriza. Mikoriza juga diduga mampu menyuplai ZPT yang yang berguna untuk perkembangan dan pembesaran akar. Derajat infeksi mikoriza diakar berpengaruh terhadap sintesis senyawa auksin dan sitokinin pada akar. Badal (2009) menyatakan bahwa pada saat infeksi mikoriza yang optimal, diyakini konsentrasi sitokinin dan auksin yang terdapat didalam sel-sel akar optimal, sehingga proses pembesaran dan diferensiasi sel-sel akar dipacu secara maksimal. Sel-sel akar yang sudah mengalami pembesaran dan difrensiasi selanjutnya menerima fotosintat dari tajuk. 


\section{Serapan Hara P}

Hasil sidik ragam serapan hara $\mathrm{P}$ menunjukkan bahwa faktor tunggal masingmasing perlakuan berpengaruh sangat nyata terhadap serapan hara $\mathrm{P}$, sedangkan interaksi mikoriza dan mikroba pelarut fosfat tidak berpengaruh nyata terhadap serapan hara P. Aplikasi mikoriza dan mikroba pelarut fosfat serta interaksinya terhadap serapan hara $\mathrm{P}$ disajikan pada Tabel 2.

Tabel 2. Rerata serapan hara $\mathrm{P}$ dengan pemberian mikoriza dan mikroba pelarut fosfat pada lahan sawah.

\begin{tabular}{|c|c|c|c|c|}
\hline \multirow[b]{2}{*}{ Mikoriza } & \multicolumn{3}{|c|}{ Penicillium sp $20 \mathrm{~mL} /$ tanaman } & \multirow[b]{2}{*}{ Rataan } \\
\hline & $\begin{array}{c}\text { Tanpa } \\
\text { Penicillium }\end{array}$ & $\begin{array}{c}\text { Penicillium sp } \\
\text { Mursala }\end{array}$ & $\begin{array}{l}\text { Penicillium sp } \\
\text { Lab }\end{array}$ & \\
\hline --g/tanaman-- & \multicolumn{4}{|c|}{ 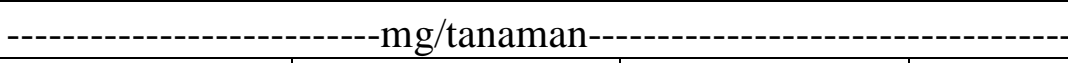 } \\
\hline 0 & 1,33 & 1.95 & 2,15 & 1,81 \\
\hline 5 & 1,83 & 2,00 & 2,30 & 2,04 \\
\hline 10 & 1,55 & 2,41 & 2,46 & 2,14 \\
\hline 15 & 1,59 & 3,41 & 3,20 & 2,74 \\
\hline Rataan & $1,58 \mathrm{~b}$ & $2,44 \mathrm{a}$ & $2,74 \mathrm{a}$ & \\
\hline
\end{tabular}

Keterangan : Angka yang diikuti notasi yang sama pada kolom atau baris yang sama menunjukkan berbeda tidak nyata menurut Uji Jarak Berganda Duncan pada taraf $5 \%$

Dari Tabel 2 menunjukkan bahwa kombinasi dan masing-masing perlakuan dari mikoriza dan mikroba pelarut fosfat dapat meningkatkan serapan hara $\mathrm{P}$ pada tanaman. Serapan hara P tertinggi diperoleh pada aplikasi kombinasi mikoriza 15 g/tanaman dan Peniciliium sp Mursala yaitu 3,41 mg/tanaman. Aplikasi faktor tunggal mikoriza 15 meningkatkan serapan P sebesar 2,74 mg/tanaman dan berbeda nyata dengan aplikasi lainnya. Aplikasi Penicillium sp Lab $20 \mathrm{~mL}$ tidak berbeda nyata dengan aplikasi Penicillium sp Mursala $20 \mathrm{~mL}$ dalam meningkatkan serapan $\mathrm{P}$ yaitu 2,74 mg/tanaman dan 2,44 mg/tanaman, namun berbeda nyata dengan tanpa aplikasi mikoriza. Hal ini menunjukkan bahwa mikoriza dan mikroba pelarut fosfat memiliki kemampuan masing-masing dalam meningkatkan serapan hara P.

Infeksi mikoriza diketahui dapat meningkatkan pertumbuhan tanaman karena adanya peningkatan dalam pengambilan hara. Derajat infeksi dan serapan $\mathrm{P}$ pada kacang hijau, sehingga akar dengan derajat infeksi yang tinggi juga akan menghasilkan serapan P yang tinggi. Hal ini sesuai dengan literatur Sitrianingsih (2010), yang menyatakan bahwa pengambilan nitrogen, fosfor, dan potasium dibatasi oleh tingkat difusi dari masing-masing unsur di dalam tanah. Namun dengan adanya mikoriza dapat meningkatkan pengambilan hara melalui difusi nutrien dari dalam tanah ke akar karena bidang penyerapan oleh hifa mikoriza yang lebih luas, sehingga meningkatkan pertumbuhan tanaman.

\section{Persentase Polong Bernas}

Jurnal Insitusi Politeknik Ganesha Medan 
Hasil sidik ragam persentase polong bernas menunjukkan bahwa interaksi mikoriza dan mikroba pelarut fosfat serta faktor tunggal mikroba pelarut fosfat tidak berpengaruh nyata terhadap persentase polong bernas, sedangkan faktor tunggal mikoriza berpengaruh nyata terhadap persentase polong bernas. Pemberian mikoriza dan mikroba pelarut fosfat serta interaksinya terhadap persentase polong bernas disajikan pada Tabel 3.

Tabel 3. Rerata persentase polong bernas dengan pemberian mikoriza dan mikroba pelarut fosfat pada lahan sawah.

\begin{tabular}{|c|c|c|c|c|}
\hline \multirow[b]{2}{*}{ Mikoriza } & \multicolumn{3}{|c|}{ Penicillium sp $20 \mathrm{~mL} / \mathrm{tanaman}$} & \multirow[b]{2}{*}{ Rataan } \\
\hline & $\begin{array}{c}\text { Tanpa } \\
\text { Penicillium }\end{array}$ & $\begin{array}{l}\text { Penicillium sp } \\
\text { Mursala }\end{array}$ & $\begin{array}{l}\text { Penicillium sp } \\
\text { Lab }\end{array}$ & \\
\hline --g/tanaman-- & \multicolumn{4}{|c|}{ 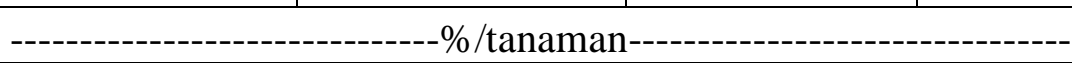 } \\
\hline 0 & 87,16 & 87,56 & 88,19 & $87,64 \mathrm{~b}$ \\
\hline 5 & 87,35 & 88,67 & 87,27 & $87,76 \mathrm{~b}$ \\
\hline 10 & 88,32 & 89,57 & 85,81 & $87,90 \mathrm{~b}$ \\
\hline 15 & 91,36 & 93,27 & 89,75 & $91,46 \mathrm{a}$ \\
\hline Rataan & 88,55 & 89,77 & 87,75 & \\
\hline
\end{tabular}

Keterangan : Angka yang diikuti notasi yang sama pada kolom yang sama menunjukkan berbeda tidak nyata menurut Uji Jarak Berganda Duncan pada taraf $5 \%$

Dari Tabel 3 menunjukkan bahwa perlakuan dari mikoriza dapat meningkatkan persentase polong bernas pada tanaman kacang hijau. Persentase polong bernas tertinggi ditunjukkan pada aplikasi kombinasi mikoriza $15 \mathrm{~g}$ dan Peniciliium $\mathrm{sp}$ Mursala yaitu 93,27\%. Aplikasi faktor tunggal mikoriza $15 \mathrm{~g} /$ tanaman meningkatkan persentase polong bernas sebesar $91,46 \%$ dan berbeda nyata dengan perlakuan lainnya. Hasil terendah ditunjukkan pada tanpa aplikasi mikoriza yaitu 87,64, namun tidak berbeda nyata dengan aplikasi mikoriza $5 \mathrm{~g} / \mathrm{tanaman}$ dan mikoriza $10 \mathrm{~g} /$ tanaman yaitu masing-masing 87,76\% dan 87,90\%. Hal ini menunjukkan bahwa mikoriza dan kombinasi antara mikoriza dan mikroba pelarut fosfat memiliki kemampuan dalam meningkatkan persentase polong bernas.

\section{Bobot 100 Biji/Tanaman}

Hasil sidik ragam bobot 100 biji per tanaman menunjukkan bahwa faktor tunggal mikroba pelarut fosfat berpengaruh sangat nyata terhadap bobot 100 biji per tanaman, faktor tunggal mikoriza berpengaruh nyata terhadap bobot 100 biji per tanaman, sedangkan interaksi mikoriza dan mikroba pelarut fosfat tidak berpengaruh nyata terhadap bobot 100 biji per tanaman. Pemberian mikoriza dan mikroba pelarut fosfat serta interaksinya terhadap bobot 100 biji per tanaman disajikan pada Tabel 4.

Tabel 4. Rerata bobot 100 biji kacang hijau dengan pemberian mikoriza dan mikroba pelarut fosfat pada lahan sawah. 


\begin{tabular}{|c|c|c|c|c|}
\hline \multirow[b]{2}{*}{ Mikoriza } & \multicolumn{3}{|c|}{ Penicillium sp $20 \mathrm{~mL} / \mathrm{tanaman}$} & \multirow[b]{2}{*}{ Rataan } \\
\hline & $\begin{array}{c}\text { Tanpa } \\
\text { Penicillium } \\
\end{array}$ & $\begin{array}{c}\text { Penicillium sp } \\
\text { Mursala }\end{array}$ & $\begin{array}{l}\text { Penicillium sp } \\
\text { Lab }\end{array}$ & \\
\hline --g/tanaman-- & \multicolumn{4}{|c|}{ 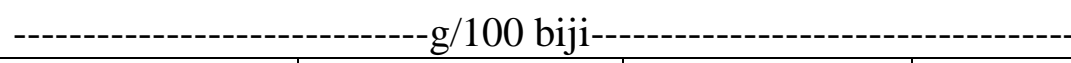 } \\
\hline 0 & 5,01 & 6,20 & 6,03 & $5,75 \mathrm{~b}$ \\
\hline 5 & 5,82 & 6,20 & 6,02 & $6,01 \mathrm{ab}$ \\
\hline 10 & 5,81 & 6,45 & 6,14 & $6,13 \mathrm{a}$ \\
\hline 15 & 5,96 & 6,67 & 6,22 & $6,29 \mathrm{a}$ \\
\hline Rataan & $5,65 \mathrm{~b}$ & $6,38 \mathrm{a}$ & $6,10 \mathrm{a}$ & \\
\hline
\end{tabular}

Keterangan : Angka yang diikuti notasi yang sama pada kolom atau baris yang sama menunjukkan berbeda tidak nyata menurut Uji Jarak Berganda Duncan pada taraf $5 \%$

Dari Tabel 4 menunjukkan bahwa kombinasi dan masing-masing perlakuan dari mikoriza dan mikroba pelarut fosfat dapat meningkatkan bobot 100 biji per tanaman dibandingkan tanpa perlakuan. Aplikasi kombinasi mikoriza $15 \mathrm{~g} / \mathrm{tanaman}$ dan Peniciliium sp Mursala menunjukkan hasil tertinggi yaitu 6,67 g/100 biji. Aplikasi faktor tunggal mikoriza $15 \mathrm{~g} /$ tanaman meningkatkan rataan bobot 100 biji per tanaman tertinggi yaitu $6,29 \mathrm{~g} /$ tanaman, namun tidak berbeda nyata dengan aplikasi mikoriza $10 \mathrm{~g} /$ tanaman dan mikoriza $5 \mathrm{~g} / \tan a m a n$ yaitu 6,13 g/tanaman dan 6,01 $\mathrm{g} /$ tanaman, sedangkan pada faktor tunggal aplikasi Penicillium sp Mursala $20 \mathrm{~mL}$ menunjukkan hasil tertinggi yaitu $6,38 \mathrm{~g} / \mathrm{tanaman}$, namun tidak berbeda nyata dengan aplikasi Penicillium sp Lab $20 \mathrm{~mL}$ yaitu 6,10 g/tanaman.

Hal diatas menunjukkan bahwa kombinasi serta faktor tunggal mikoriza dan mikroba pelarut fosfat memiliki kemampuan dalam meningkatkan bobot 100 biji/tanaman. Meningkatnya bobot 100 biji diduga kerena meningkatnya serapan hara $\mathrm{P}$ oleh tanaman, sehingga tanaman dengan serapan $\mathrm{P}$ yang tinggi juga akan menghasilkan bobot 100 biji yang tinggi. Suratmin dkk (2002) menyatakan bahwa $\mathrm{P}$ berfungsi sebagai penyusun lemak dan protein, unsur hara $\mathrm{P}$ merupakan pembentuk inti sel dan dapat mempercepat proses-proses fisiologis. Fungsi dari fosfor mempercepat pertumbuhan akar, memperkuat batang, mempercepat proses pembungaan, pengisian biji, mempercepat pemasakan buah dan meningkatkan produksi biji-bijian.

\section{KESIMPULAN}

Aplikasi mikoriza $15 \mathrm{~g} /$ tanaman merupakan dosis terbaik untuk meningkatkan serapan $\mathrm{P}(2,74 \mathrm{mg} / \mathrm{tanaman})$ dan produksi kacang hijau. Interaksi antara mikoriza $15 \mathrm{~g} /$ tanaman dan Penicillium sp Mursala meningkatkan serapan P (3,20 $\mathrm{mg} /$ tanaman) dan produksi kacang hijau. Interaksi mikoriza $15 \mathrm{~g} / \mathrm{tanaman}$ dan Penicillium sp Mursala menghasilkan bobot 100 biji/tanaman sebesar 6,67 g/tanaman. 


\section{DAFTAR PUSTAKA}

Badal, B. 2009. Pemanfaatan Cendawan Mikoriza Vesikular Arbuskular (CMA) dalam pembibitan tanaman kopi (Coffea robusta L.) pada Ultisol. Jurnal. Embrio, vol 2 (1) : 26-31.

BPS Indonesia. 2015. Rata-Rata Produksi Kacang Hijau Menurut Kabupaten/Kota. Badan Pusat Statistik Indonesia.

Badan Pusat Statistik. 2014. Laporan Hasil Sensus Pertanian 2013. Badan Pusat Statistik. Jakarta.

Campbel, N. A., Reece, J. B. 2010. Biologi : Edisi kedelapan Jilid 2. Penerbit Erlangga. Jakarta.

Dinas Pertanian dan Ketahanan Pangan. 2012. Kacang Hijau di Kabupaten Gorontalo. Gorontalo.

Dostalova, J.P.K. 2009. The Changes of - Galaktosidase during Germination and High Pressure Treament of Legume Seeds. Czech J. Food Sience, S76.

Elfiati, D. 2005. Peranan Mikroba Pelarut Fospat Terhadap Pertumbuhan Tanaman. Kehutanan, Fakultas Pertanian Universitas Sumatera Utara. Medan.

Fuady, Z. 2013. Kontribusi cendawan mikoriza arbuskular terhadap pembentukan agregat tanah dan pertumbuhan tanaman. Jurnal lentera13(3)

Hardjowigeno. S dan L. Rayes. 2005. Karakteristik, kondisi dan permasalahan tanah sawah di Indonesia.. Bayumedia Publishing. Malang.

Husna, 2016. Respons tanaman kacang hijau (Phaseolus radiatus L.) terhadap aplikasi fungi mikoriza arbuskular dan dosis bahan organik yang berbeda pada tanah ultisols. Skripsi. Fakultas pertanian universitas lampung bandar lampung.

Husen, E, 2009. Telaah Efektifitas Pupuk Hayati Komersial Dalam Meningkatkan Pertumbuhan Tanaman. Balai Penelitian Tanah. Bogor.

Madjid, A. 2009. Peran dan Prospek Mikoriza.Program Pascasarjana. Universitas. Sriwijaya, Palembang

Paluhulawa, Citra. 2014. Pertumbuhan Dan Produksi Kacang Hijau (Vigna Radiata L) Melalui Pemberian Pupuk Organik dan Anorganik Tumpang Sari Dengan Jagung Manis Pada Sistem Tanaman Legowo. Skripsi. Jurusan Agreteknologi Fakultas Pertanian Universitas Negeri Gorontalo. Gorontalo.

Jurnal Insitusi Politeknik Ganesha Medan

Juripol, Volume 4 Nomor 2 Septembar 2021 
Ponmurugan, $\mathrm{P}$ dan C Gopi. 2006. Distribution pattern and screening of phosphatase solubilizing bacteria isolated from different food and forage crops. Journal of Agronomy, vol 5 : 600 - 604 .

Sitrianingsih. 2010. Pengaruh Inokulasi Mikoriza Vesikula Arbuskula (MVA) Terhadap Pertumbuhan Bibit Pule Pandak (Rauvolfia verticillata Lour.) Naskah Publikasi. Jurusan Biologi Fakultas Matematika dan Ilmu Pengetahuan Alam Universitas Sebelas Maret Surakarta.

Suratmin, D. Wakano, D. Badwi. 2017. Penggunaan pupuk kompos dan pupuk fosfor terhadap pertumbuhan tanaman kacang hijau. Jurnal Biology Science \& Education, vol 6 (2) : $148-158$. 